\title{
ANALISIS MODEL TA'DIB DALAM PEMBELAJARAN ISLAM
}

\author{
Ita Tryas Nur Rochbani \\ Sekolah Kalista Batam, Dinas Sosial Batam \\ ItaTNRoc@gmail.com
}

\begin{abstract}
Problems that will be studied in this research, that is: model of ta'dib based PAI curriculum policy in improving student learning and its supporting and inhibiting factors. This research is motivated by the problem kuranngnya role of government, parents and teachers in education. Which one puts forward the cognitive domain and puts aside the importance of adab in measuring student success. The purpose of education is to give birth to a perfect human being that is civilized human (kamil man). The ta'dib curriculum can improve students 'learning by two main factors namely learning method (ie using Tauhid Method) and learning materials that are in accordance with the target of Islamic religious education (ie fardu' ain) and rational, intellectual and philosophical (fardhu kifayah). The factors supporting and inhibiting the ta'dibbased curriculum are: 1) Parents who look far ahead, the importance of character and the planting of religious knowledge from an early age, 2) Some of the educators who want the next generation of nation has a noble character and always leading to the norms according to the religious shari'a, 3) Some governments who agree on the ta'dib-based curriculum can be applied in every educational institution. While Inhibiting Factors Policy of PAI Based Ta'dib curriculum, are: 1) Problem of concept or thinking of government which is more concerned with cognitive aspect compared with process or ta'dibnya learners, 2) Purpose of parent who put forward the cognitive domain, so forget about karekteristik and the behavior of children, 3) The era of continuous changes and the era of globalization is high, so the child's cognitive importance of the child's character.
\end{abstract}

Keywords: Policy Model, Ta'dib Curriculum

\section{PENDAHULUAN}

Pendidikan bagi manusia atau masyarakat dipandang sebagai human investment. Ini berarti bahwa secara historis maupun filosofis, pendidikan telah mewarnai dan 
menjadi landasan moral dan etika dalam proses pembentukan jati diri bangsa (Abuddin Nata 2003). Salah satu bukti otentiknya dinyatakan dalam Tujuan Pendidikan Nasional (UUSPN Tahun 1989 BAB II pasal 4) (Undang-Undang Republik Indonesia No 20 Tahun 2003). Sasaran pendidikan yang dimaksud dalam tujuan pendidikan nasional adalah tercapainya "manusia seutuhnya" yang ciri utamanya beriman dan bertaqwa kepada Tuhan Yang Maha Esa, dengan atribut lainnya yang menyangkut dimensi cipta, rasa, dan karsa (kognitif, afektif, dan psikomotorik) (Redja Mudyahardjo 2014). Pendidikan pada dasarnya adalah mengtransformasikan nilai-nilai pengetahuan dan keterampilan yang dilakukan secara sistematis dan berkesinambungan. Pendidikan tidak hanya berupa pengajaran di kelas saja, dalam kenyataanya pendidikan adalah proses dimana suatu bangsa atau Negara membina dan mengembangkan kesadaran diri diantara individu-individu lainya (AlFikra, 2004). Dengan kesadaran tersebut suatu bangsa atau Negara dapat mewariskan kekayaan budaya atau pemikiran kepada generasi berikutnya, sehingga menjadi inspirasi bagi mereka dalam setiap aspek kehidupan. Sebagaimana firman Allah dalam al-Quran surah Ali-Imran ayat 104 yakni:Artinya: "Dan hendaklah ada diantara kamu segolongan umat yang menyeru kepada kebajikan, menyuruh kepada yang ma'ruf dan mencegah dari yang munkar merekalah orangorang yang beruntung".

Dapat dikatakan bahwa pendidikan merupakan penolong umat bagi manusia untuk menjalani kehidupan. Tanpa pendidikan maka manusia sekarang tidak akan berbeda dengan keadaan terdahulu pada masa purbakala. Asumsi ini dapat disimpulkan bahwa maju mundurnya atau baik buruknya suatu bangsa ditentukan oleh kondisi pendidikan yang dijalani oleh suatu bangsa tersebut. Pendidikan nasional selalu menghadapi tantangan sesuai dengan zamannya. Sejak kemerdekaan sampai sekarang ini, oleh karena itu dunia pendidikan menghadapi tantangan yang sangat berat untuk meningkatkan kualitas bangsa secara keseluruhan. Dalam upaya menyingkapi beratnya tantangan ini, bagi bangsa Indonesia perlu lebih meningkatkan mutu pendidikan yang ada, salah satunya yakni Pendidikan Islam.

Pendidikan Islam adalah sistem pendidikan yang sengaja didirikan dan diselenggarakan dengan hasrat dan niat (rencana yang sungguh-sungguh) (Muhaimin 2014), untuk menanamkan ajaran dan nilai-nilai Islam, sebagaimana tertuang dalam visi, misi, tujuan, dan pelaksanaan pendidikan. Pengembangan kurikulum Pendidikan Agama Islam (PAI) merupakan salah satu perwujudan dari pengembangan sistem pendidikan Islam.Di tengah-tengah pesatnya inovasi pendidikan, terutama dalam konteks pengembangan kurikulum, sering kali para guru PAI merasa kebingungan dalam menghadapinya. Apalagi inovasi pendidikan tersebut cenderung bersifat top-down innovation dengan strategi power coercive atau strategi pemaksaan dari atasan (pusat) yang berkuasa. (Ahmad D. Marimba 1998) inovasi ini sengaja diciptakan oleh atasan sebagai usaha untuk meningkatkan 
mutu pendidikan di Indonesia ini, dengan cara mengajak dan memberi pemahaman akan kebijakan tersebut. Karena itu, ada kesan yang cukup memprihatinkan dari masyarakat bahwa seolah-olah setiap ganti menteri akan ada juga kebijakan-kebijakan baru yang dibuat dan harus dilakukan oleh kalangan-kalangan dibawahnya. Padahal kebijakan yang terdahulu masih belum sempurna, tetapi sudah memunculkan kebijakan baru, yang membuat resah semua kalangan.

Untuk mengantisipasi masalah tersebut, para peranan pendidikan dan para guru PAI perlu memahami dan memiliki dasar landasan yang kuat untuk dijadikan patokan dan acuan yang jelas. Sebab kebanyakan dari inovasi tersebut dibangun bukan dari eksperimen pendidikan agama, tetapi dari bidang lain yang memiliki karakteristik yang berbeda pula, sedangkan pendidikan agama hanya bersifat latah.

Sebagaimana tertuang dalam UU Nomor 20/2003 tentang Sistem Pendidikan Nasional, terutama pada penjelasan Pasal 37 ayat (1) bahwa pendidikan agama dimaksudkan untuk membentuk peserta didik menjadi manusia yang beriman dan bertaqwa kepada Tuhan Yang Maha Esa serta berakhlak mulia. Prinsip kebijakan kurikulum di Indonesia ini, terkhususnya Pendidikan Agama Islam (PAI), ialah memantapkan visi dan misi pendidikan agama di setiap kalangan. Agar dapat membantu peserta didik dalam mewujudkan nilai dasar agama dalam menerapkan ilmu pengetahuan, teknologi dan seni.Demikian pula halnya dengan peranan pendidikan Islam, di kalangan umat Islam merupakan salah satu bentuk manifestasi dari cita-cita untuk melestarikan dan mentransformasikan ajaran Islam kepada pribadi dan generasi penerus, sehingga nilai-nilai religius yang dicita-citakan dapat berfungsi dan berkembang dalam masyarakat dari waktu ke waktu.

Pendidikan Islam adalah bimbingan jasmani dan rohani berdasarkan hukum-hukum agama Islam menuju kepada terbentuknya kepribadian utama menurut ukuran Islam atau memiliki kepribadian muslim (Ahmad D. Marimba 1981). Selanjutnya Mushtafa al-Gulayani berpendapat bahwa pendidikan Islam adalah menanamkan akhlaq mulia ke dalam jiwa anak dalam masa pertumbuhannya dan menyiraminya dengan petunjuk dan nasihat, sehingga akhlaq mereka menjadi salah satu kemampuan yang meresap dalam jiwanya dan mewujudkan keutamaan kebaikan, dan cinta bekerja bagi kemanfaatan tanah air (Mushtafa 1997). Sebagaimana firman Allah SWT. dalam al-Qur'an Surah An-Nahl ayat 125, yakni:Artinya: "Serulah (manusia) kepada jalan Tuhan-mu dengan hikmahdan pelajaran yang baik dan bantahlah mereka dengan cara yang baik. Sesungguhnya Tuhanmu Dialah yang lebih mengetahui tentang siapa yang tersesat dari jalan-Nya dan Dialah yang lebih mengetahui orang-orang yang mendapat petunjuk". (Departemen Agama RI 2005)

Dunia pendidikan di Indonesia saat ini tengah menghadapi problema yang cukup berat dan kompleks. Salah satunya bentuk kriminalitas terhadap para pelajar, contoh lain banyaknya terjadi tawuran antar pelajar. Tawuran pelajar atau perkelahian pelajar adalah salah satu bentuk kenakalan 
remaja. Adapun salah satu contoh yang sangat viral sekarang ialah pelajar menganiaya guru.(Tribun News.com 2018) Ini adalah suatu bukti akan kurangnya iman dan akhlak pada anak. Walaupun hanya salah satu dari perilaku kenakalan tetapi sangat mengganggu keharmonisan dan merupakan sebagai problem sosial dan dapat menjadi bencana Nasional (Sudarsono 1993).Kenakalan para pelajar ini terjadi karena kurangnya sinkronisasi antar pihak sekolah dengan keluarga pelajar. Terkadang apa yang di dapat di sekolah, tidak semua anak bisa mengaplikasikanya dengan baik ketika berada di luar sekolah.Contoh real yang bisa dirasakan adalah ketika nasehat para orang tua jauh lebih diabaikan, sedangkan perkataan guru lebih didengar oleh anak ataupun sebaliknya. Seharusnya anak bisa menyeimbangkan antara nasehat orang tua dan guru secara seimbang, sehingga ilmu yang didapat lebih melekat dan berkah. Contoh yang lainya ketika ada anak yang bersekolah di sekolah yang berbasis agama, mereka akan terlihat rajin beribadah di sekolah, daripada di rumah sendiri (Wawancara 2017).

Kurangnya perhatian orang tua juga salah satu faktor yang memicu terjadinya tidak sinkronisasi ini. Karena anak kurang menjiwai rutinitas yang seharusnya mereka lakukan dimanapun dan kapanpun. Contohnya ibadah sholat bagi yang muslim, mereka melakukan sholat belum berasal dari dalam hati, tetapi melakukannya karena takut kepada guru di sekolah. Disinilah peran orang tua yang harus digalakkkan dan ditegaskan kepada para anakanak penerus masa
depan.Pemaparan kejadian diatas dapat diasumsikan, pendidikan yang berasal dari keluarga lebih utama, daripada anak tersebut mendapatkan pelajaran utama yang berawal di bangku sekolah. Sebagaimana dalam firman Allah SWT. dalam al-Qur'an Surah AliImron ayat 6 , yang berbunyi: Artinya: "Dialah yang membentuk kamu dalam rahim menurut yang Dia kehendak. Tidak ada Tuhan selain Dia. Yang Mahaperkasa, Mahabijaksana". (Departemen Agama RI, 2005)

Dari ayat di atas, penafsiran penulis ialah bahwa pengaruh orang tua sangat besar bagi masa depan anak.Untuk merenungkan tanggung jawab penting orang tua terhadap anak-anak mereka, kita baca sebuah riwayat, bahwa seorang laki-laki datang kepada Rasulullah SAW dan berkata, (Husain Mazhahiri199) "Wahai Rasulullah, apa hak anakku ini?" Rasulullah menjawab, "Anda beri nama dan mendidik sopan santun yang baik padanya, dan Anda letakkan dia pada posisi yang baik." Tidaklah sulit bagi orang tua hanya mengantarkan anak mereka menuju tingkatan sopan santun saja, tetapi yang sulit adalah meletakkannya pada posisi yang baik dalam segala sikap dan tujuan hidupnya.

Di zaman sekarang ini banyak yang menyerahkan pendidikan anakanaknya di bangku sekolah, sedangkan orang tua sibuk bekerja dari pagi sampai malam hari. Bahkan tidak ada interaksi antara orang tua dan anak, yang mana hal ini sangat merugikan bagi anak.Di dunia pendidikan sekarang ini, lebih banyak yang mementingkan hasil daripada proses. Dari segi kognitif, afektif, dan psikomotorik. Anak-anak 
dituntut untuk mengetahui, memahami bahkan menghafalkan semua pelajaran yang di dapat dalam waktu yang bersamaan. Sedangkan praktek dari itu semua dilaksanakan ketika mereka sudah menghafalnya. Alangkah baiknya jika pendidikan anak-anak di mulai dari lingkungan keluarga. Di tanamkan dalam hati dan jiwa mereka akan pentingnya ilmu yang mereka hafalkan tersebut. Sehingga mereka melakukan ibadah terasa lebih menjiwai tidak terkesan memaksa.

Seperti pendidikan Islam yang telah diajarkan Rasulullah, mengajarkan dan menanamkan ilmu agama mulai dari dini, meskipun mereka belum memahami tujuan bahkan manfaat bagi mereka sendiri. Ta'dib lebih di dahulukan, kemudian setelah mereka sudah terbiasa dalam pembelajaran, barulah mereka mengenal ilmu tersebut, yang sering disebut dengan ta'lim dan tarbiyah. Adapun konsep kunci yang merupakan inti pendidikan dan proses pendidikan adalah Adab. Karena Adab adalah disiplin tubuh, jiwa, dan ruh yang menegaskan pengenalan dan pengakuan mengenai posisi yang tepat mengenai hubungannya dengan potensi jasmani, intelektual, dan ruhaniyahn (Naquib Al-Attas 1992).Dan di Indonesia juga sudah menggunakan kurikulum yang umum tidak terfokus kedalam ranah keagamaan saja, terkhususnya di dalam pembuatan evaluasi pembelajaran dan cara penyampaian materi, tidak terkecuali di mata pelajaran Pendidikan Agama Islam (PAI). Anak dituntut untuk menghafal tanpa diberi pemahaman yang lebih akan guna ilmu itu sendiri. Dan disini banyak sekali terjadi kurangnya sinkronisasi antara guru dan orang tua, dan kurangnya seimbang antara tujuan dunia dan akhiratnya. Begitu juga kurangnya perhatian khusus di kalangan pemerintah.

Peran pemerintah sangatlah penting dalam memajukan pendidikan di era sekarang ini. Untuk mendukung kualitas kurikulum yang baik dan bermutu, guna memajukan nusa dan bangsa terkhususnya dalam aspek kurikulum Pendidikan Agama Islam (PAI). Karena dengan kurikulum yang baik dan tersistem dapat membuat guru dan para pendidik lainnya dapat mengerti arah kebijakan kurikulum yang sebenarnya.

\section{PEMBAHASAN}

Menurut Bahasa (etimologi) kurikulum berasal dari bahasa Yunani, yaitu Curir yang artinya pelari dan Curere yang berarti jarak yang harus ditempuh oleh pelajar (S. Nasution, 2006). Dalam bahasa Arab, istilah "kurikulum"diartikan dengan Manhaj(Muhaimin 2007), yakni jalan yang terang, atau jalan terang yang dilalui oleh manusia dalam bidang kehidupannya. Dalam kamus Bahasa Indonesia Kontemporer kurikulum berarti perangkat mata pelajaran yang diberikan pada lembaga pendidikan (Peter Salim dan Yenni Salim 1991).Berdasarkan studi yang telah dilakukan oleh banyak ahli, kurikulum dapat ditinjau dari dua sisi yang berbeda, yakni menurut pandangan lama dan pandangan baru. Pandangan lama, atau sering juga disebut pandangan tradisional, merumuskan bahwa kurikulum adalah sejumlah mata pelajaran yang harus ditempuh murid untuk 
memperoleh ijazah (Oemar Hamalik 2007).

Kurikulum merupakan niat dan harapan yang dituangkan dalam bentuk rencana atau program pendidikan untuk dilaksanakan oleh guru di sekolah. Isi kurikulum adalah pengetahuan ilmiah, termasuk kegiatan dan pengalaman belajar, yang disusun sesuai dengan taraf perkembangan siswa. Kurikulum akan mempunyai arti dan fungsi untuk mengubah siswa apabila dilaksanakan dan ditransformasikan oleh guru kepada siswa dalam suatu kegiatan yang disebut proses belajar mengajar. Dengan kata lain proses belajar mengajar adalah operasionalisasi dari kurikulum (Nana Sudjana 1991) Kurikulum menjadi inti dan kunci kesuksesan maupun kegagalan suatu pendidikan yang diperankan oleh pendidik atau guru. Oleh karena itu dalam penyusunan kurikulum diperlukan sebuah ketelitian guna menghasilkan mutu (out put) pendidikan sebagaimana yang diharapkan (Hasan Langgulung 2000).

Menurut al-Attas kurikulum yang sempurna itu dapat terwujud tidak lain dengan memahami hakikat dari manusia itu sendiri. Dalam Islam, manusia adalah makhluk yang sempurna dan lebih mulia di bandingkan dengan mahkluk lainnya. Karena manusia memiliki dua hakikat yaitu jiwa dan raga atau jasmani dan ruh (Al-Attas 1990).Sebagaimana dikatakan dalam kitab suci Al-Qur'an surah alMu'minun ayat 12-14 yang berbunyi: Artinya: (12). Dan Sesungguhnya Kami telah menciptakan manusia dari suatu saripati (berasal) dari tanah. (13). Kemudian Kami jadikan saripati itu air mani (yang disimpan) dalam tempat yang kokoh (rahim).(14). Kemudian air mani itu Kami jadikan segumpal darah, lalu segumpal darah itu Kami jadikan segumpal daging, dan segumpal daging itu Kami jadikan tulang belulang, lalu tulang belulang itu Kami bungkus dengan daging. kemudian Kami jadikan Dia makhluk yang (berbentuk) lain. Maka Maha sucilah Allah, Pencipta yang paling baik(Departemen Agama RI 2005).Sebagaimana juga, terdapat dalam surah Al-Hijr ayat 29, yang berbunyi:Artinya: "Maka apabila aku telah menyempurnakan kejadiannya, dan telah meniupkan kedalamnya ruh (ciptaan)-Ku, Maka tunduklah kamu kepadanya dengan bersujud" 9Departemen Agama RI 2005).

Menurut al-Attas, untuk mewujudkan manusia yang beradab dalam kehidupan ini, maka dibutuhkan bentuk kurikulum pendidikan yang baik pula, kurikulum mesti dapat mengambarkan manusia universal atau sempurna (al-insanul kamil). Dalam Islam, manusia universal atau sempurna (al-insanul kamil) bentuk dari keberhasilan kurikulum pendidikan Islam itu ada dalam diri Rasulullah saw (Al-Attas 1990). Di bawah ini akan dijelaskan pandangan al-Attas mengenai bentuk-bentuk kurikulum dalam pendidikan Islam tersebut:

\section{Tujuan Kurikulum Berbasis Ta'dib \\ Menurut al-Attas, tujuan} pendidikan adalah untuk melahirkan "manusia yang baik" bukan sekedar manusia sebagai warga negara atau bagian yang tak terpisahkan dari masyarakat (Al-Attas 1990). Adapun yang dimaksudkan dengan manusia 
yang baik di sini adalah manusia yang beradab atau adabi. Manusia adabi adalah:Manusia yang sadar insaf akan tangungjawabnya kepada Allah SWT sebagai Tuhan yang senantiasa disembah; yang memahami dan melaksanakan tangungjawabnya kepada diri sendiri. Dan kepada masyarakat dengan adil dan yang senantiasa berusaha memperbaik setiap aspek dirinya ke tahap yang lebih sempurna (Al-Attas 1990).

Dalam arti lain, manusia yang terserap adabdalam dirinya adalah manusia yang faham "hakikat tujuan hidupnya".

Sebagaimana disampaikan oleh Rasulullah saw dalam sabdanya; "manusia yang sempurna adalah manusia yang paling baik pencapaian takwa dan akhlaknya". Nabi Muhammad saw adalah perwujudan keutamaan dan ketingian pencapaian takwa dan akhlak tersebut. Nabi saw sendiri mengatakan dalam hadis yang telah dikutip sebelumnya, bahwa Allah SWT menanamkan adab ke dalam dirinya dan dengan demikian menjadikan didikannya (ta'dibnya) yang terbaik. Rasulullah saw menginggatkan kepada umatnya bahwa tujuan beliau diutus adalah untuk mendidik akhlak yang mulia "Innamābu'ithtu li-utammima makārim al-akhlāq" (Wahbah AzZuhaili 2002).Baginda saw juga pernah bersabda, bahwa "muslim yang sempurna keimanannya adalah unggul akhlaknya" (akma lu'lmu'minin imananahsanuhum khulqan) (Wan Daud 2007). Maka tidak heranlah Rasulullah SAW disebut sebagai rahmat bagi keseluruh alam (rahmatan lil 'alamin).

Menurut pandangan penulis, bila berbicara tujuan perndidikan, maka sebagaimana diketahui bahwa semua sarjana dan cendikiawan muslim sepakat bahwa tujuan pendidikan adalah mewujudkan atau membentuk manusia yang bersifat mulia, shaleh dan cerdas. Inilah inti dari konsep adab dan pendidikan Islam. Dalam Islam, adab memiliki hubungan dengan aqidah. Adab dalam pengertian al-Attas mencakup hubungan, manusia dengan Sang Khaliqnya Allah SWT. dan manusia dengan sesama manusia, manusia dengan alam (Al-Attas 1990). Tujuan ini, sebagaimana digambarkan dalam hadis nabi Muhammad SAW bahwa Rasulullah SAW diutus oleh oleh Allah SWT. ke bumi ini untuk penyempurnaan perilaku atau tindakan manusia kepada kemuliaan atau kesempurnaan. Hadist tersebut adalah:Artinya: "Aku (Muhammad) hanya diutrus untuk menyempurnakan prilaku manusia yang mulia. (HR. Malik)".

Sebagaimana diketahui, bahwa pada dasarnya manusia lahir membawa fitrah. Diketahui bahwa fitrah manusia pada dasarnya cenderung pada kebaikan, sehingga ia dapat melakukan kebaikan itu. Namun karena pengaruh lingkungan, pendidikan, pergaulan dan orang tua menjadikan manusia berpotensi jahat. Oleh karena itu, Allah SWT. mengutus Nabi Muhammad SAW, sebagai rahmat bagi seluruh alam, yang menjadi tauladan cara berprilaku lahiriah dan batiniah. Keberadaannya bersifat menyeluruh dan terpadu, tidak terpecah-pecah menjadi bagianbagian yang satu sama lain berdiri sendiri-sendiri. Tujuan diutusnya Rasulullah mendidik dan membimbing umat manusia adalah untuk (Hasan Langgulung 2000): 
1) Mengenal Allah SWT. Sebagai Tujuan Dalam Hidup

Secara naluri, manusia mengakui kekuatan dalam kehidupan ini diluar dirinya. Hal ini dapat dilihat ketika manusia mengalami kesulitan-kesulitan hidup, musibah, dan berbagai bencana. la akan mengeluh dan meminta pertolongan kepada sesuatu yang serba maha, yang dapat membebaskannya dari keadaan itu. Ini dialami setiap manusia (tidak membedakan warna kulit, bangsa, tempat tinggal dan bahkan agama sekalipun). Dalam keadaan ini manusia terjepit dan tidak berdaya. Pada manusia primitif, kondisi ini menimbulkan kepercayaan animisme dan dinamisme. Adapun bentukbentuk penghormatan mereka pada Tuhannya, seperti(Hasan Langgulung 2000):

a) Sesajian-sesajian pada pohon-pohon besar, batu, gunung, sungai sungai, laut dan benda alam lainnya.

b) Pantangan-pantangan (tabu) yaitu perbuatan-perbuatan atau ucapan-ucapan yang dianggap dapat mengundang murka (kemarahan) Kepada kekuatan yang dianggap maha itu.

c) Menjaga dan mengobati kemurkaan yang ditimbulkan akibat ulah manusia, misalnya: Upacara

Persembahan, ruatan dan mengorbankan sesuatu.

Dalam Syariat Islam yang bersumber pada Al- Qur'an dan AsSunah menetapkan titik tolak adab kepada Allah adalah pengakuan dan kesadaran bahwa "Tiada Tuhan melainkan Allah SWT". Dari sinilah dapat dipahami selanjutnya, tentang kebesaran, keagungan dan kesucian Allah SWT. tidak ada satu makhluk yang dapat menyamai Allah SWT. dengan sifat-sifat kesempurnaannya.

2) Mengenal Hakikat Kehidupan Bersama Makhluk-Makhluk Ciptaan Allah SWT.

Secara alamiah, manusia sering dikatakan sebagai mahluk sosial. Artinya manusia tidak dapat hidup dan berkembang dengan baik tanpa bantuan dan interaksinya pada makhluk ciptaan Allah SWT, termasuk dalam hubungan manusia(Hasan Langgulung 2000). Hubungan manusia dengan sesama manusia adalah dalam rangka memenuhi kebutuhan-kebutuhan hidup manusia yang komplek tersebut. Baik itu kebutuhankebutuhan yang bersifat fisik (jasmaniah) maupun kebutuhankebutuhan yang bersifat psikis (rohaniah). Subtansi hubungan manusia itu pada pokoknya dalam rangka saling memenuhi kebutuhan masing-masing. Adab sebagai aturan hubungan memberikan batasan-batasan tentang perpuatanperbuatan yang harus diperbuat dan perbuatan-perbuatan yang harus ditinggalkan untuk keharmonisan interaksi.

Islam adalah agama yang sesuai dengan fitrah manusia, mengatur adab antara sesama manusia yang harus dipatuhi. Betapa banyak ayat-ayat dalam alQur'an yang menjelaskan tuntunan Islam terhadap sesama manusia, misalnya didalam surah al-Baqoroh ayat 263, yang berbunyi:Artinya: "Perkataan yang baik dan pemberian maaf lebih baik dari pada sedekah yang disertai dengan sesuatu yang menyakitkan (perasaan sipenerima)"(Departemen Agama RI, 
2005).Dan didalam al-Qur'an surah al-Isra' ayat 23, yang berbunyi:Artinya: "Dan tuhanmu telah memerintahkan supaya kamu jangan menyembah selain dia (Allah SWT) dan hendaklah kamu berbuat baik kepada kedua ibu bapakmu sebaik-baiknya. Jika salah seorang diantara keduanya atau keduaduanya sampai berusia lanjut dalam pemeliharaanmu, maka sekali-kali janganlah engkau mengatakkan kepada keduanya perkataan "ah" dan janganlah engkau membentak keduanya, dan ucapkanlah kepaada keduanya perkataan yang baik".

Berbuat baik terhadap sesama manusia adalah mutlak dilakukan oleh seseorang sebenarnya, tanpa terbatas oleh waktu, kondisi, tempat, agama dan budaya. Adab pada tatanan ini adalah fitrah manusia sebagai makhluk yang paling tinggi derajatnya dibandingkan dengan makhluk lainnya. Ketinggian derajat dan martabat manusia karena moral dan akhlaq yang akan membentuk peradapan luhur manusia. Kalau ada manusia yang bermoral bobrok dan hancur sebenarnya ia mengingkari fitrahnya sehingga orang yang hidupnya demikian tidak akan pernah menemukan kebahagiaan dan ketentraman yang abadi dalam hidupnya. Inilah yang harus menjadi bahan perenungan dalam menanamkan moral pada anak. Bentuk adab pada manusia ini meliputi: adab pada diri sendiri dan manusia di sekitarnya.

3) Mengenal Lingkungan

Sejak manusia ada di muka bumi, mereka hidup bersama alam. Mula-mula manusia hidup secara berpindah-pindah (nomaden) mencari tempat-tempat yang menyediakan hidup dan makan. Mereka lalu berpindah-pindah dari suatu tempat ketempat lain setelah bahan makanan habis dan tidak didapat. Selanjutnya semakin lama semakin maju kehidupan manusia, sehingga ada yang bercocok tanam, berdagang, pegawai dan berbagai macam profesi. Namun seiring dengan kemajuan kehidupan manusia bukan berarti ketergantungan dan kebutuhannya terhadap alam semakin berkurang. Mereka tetap membutuhkan alam bagi kemakmuran dan kesejahteraan hidupnya. Untuk itu manusia harus bisa menjaga keharmonisan hubungannya dengan alam dan makhluk sekitarnya, yaitu dengan cara berbuat baik kepadanya. Tidak kurang dalam alQur'an dan as-Sunah yang menjelaskan hal itu.

Sebagaimana dalam firman Allah SWT. didalam Al-Qur'an Surah Al-Hasyr ayat 5 yang berbunyi:Artinya: "Apa saja yang kamu tebang dari pohon kurma (milik orang-orang kafir) atau yang kamu biarkan (tumbuh) berdiri di atas pokoknya, maka (semua itu) adalah dengan izin Allah, dan karena Dia hendak memberikan kehinaan kepada orang-orang fasik". (Departemen Agama RI, 2005).

Dalam ajaran Islam, adab terhadap alam seisinya dikaitkan dengan tugas manusia sebagai khalifah dimuka bumi. Manusia bertugas memakmurkan, menjaga dan melestarikan bumi ini untuk kebutuhannya. Adab terhadap alam bukan hanya semata-mata untuk kepentingan alam, tetapi jauh dari itu untuk memelihara, melestarikan dan memakmurkan alam. Dengan kemakmuran alam dan keseimbangannya manusia dapat mencapai dan memenuhi kebutuhannya, sehingga 
kemamuran, kesejahteraan dan keharmonisan hidup dapat terjaga.

Tujuan adalah sesuatu yang ingin dicapai. Segala sesuatu itu dapat berupa benda konkrit baik yang berupa barang maupun tempat, atau dapat juga berupa halhal yang sifatnya abstrak, misalnya cita-cita yang mungkin berupa kedudukan atau pangkat/jabatan maupun sifat-sifat luhur. Dengan kata lain tujuan dapat berupa hal-hal sederhana dapat pula berupa hal-hal yang kompleks. Sedang cara penyampaiannya ada berbagai macam. Ada yang hanya kegiatan fisik, tetapi ada yang dengan cara membuat rencana dulu, diprogramkan, mencari dana baru mengerahkan tenaga baik fisik maupun psikis. Kurikulum adalah alat untuk mencapai tujuan pendidikan. Tujuan pendidikan sendiri adalah sesuatu yang abstrak, ruwet, dan kopleks (Dakir 2004).

Tujuan yang jelas dapat menjadi tuntunan dalam pengembangan komponen kurikulum lain. Tujuan yang jelas mempunyai manfaat yang sangat besar dalam pengembangan kurikulum. Tujuan itu sendiri mempunyai berbagai fungsi. Tujuan setidak-tidaknya mempunyai fungsi sebagai pemandu dalam menentukan isi kurikulum, bentukbentuk pengalaman belajar yang ingin dicapai siswa, dan penetapan kriteria yang digunakan dalam menentukan apa yang harus diajarkan serta bagaimana cara mengajarkannya (Muhammad Ali 2005).

Secara historis kebijkan kurikulum berasal dari bebarapa proses yang mana melibatkan semua pihak. Terutama bagi para pendidik yang merasakan langsung bagaimana aplikasi di lapangan, dan pihak orang tua yang merasakan perubahan sang anak didik di lingkungan rumah. Dan semua dijadikan satu, kemudian pihak pemerintah mempertimbangkan akan permasalahan yang ada, sehingga lahirnya kebijakankebijakan baru yang mana dapat meningkatkan dunia pendidikan di Indonesia.

Dalam situasi era global ini, kemajuan teknologi yang dari hari kehari semakin canggih dan perkembangan informasi komonikasi yang sangat pesat, maka kebijakan kurikulum harus menyesuaikan dengan keadaan zaman sekarang, yang mana dapat menunjang agar tercapaiknya tujuan pendidikan yang hakiki.Tujuan umum kebijakan kurikulum ialah dapat menciptakan dan mewujudkan pendidikan yang dapat memberi pembekalan dalam memadukan pengetahuan dalam penguasaan ilmu umum dan mahir dalam keagamaan yang sesuai dengan tuntunan al-Qur'an dan alHadits serta diimplementasikan dalam kehidupan sehari-hari sebagai bangsa dan warga negara NKRI yang baik.Dengan paparan diatas, terlingkuplah keinginan dan tujuan pendidikan pada umumnya. Lebih lanjut dari beberapa unsur tujuan ini bila ditarik benang merahnya adalah terdiri dari tiga program kurikulum pendidikan umum yang berpijak pada Kementerian Pendidikan Nasional dan kurikulum Pendidikan Agama yang berpijak pada Kementerian Agama serta kurikulum pendalaman agama yang berbasis ta'dib.
2. Ta'dib Dapat Meningkatkan Kurikulum
Kurikulum ta'dib dapat meningkatkan pembelajaran siswa 
dengan dua faktor utama yaitu metode pembelajaran dan materi pembelajaran yang sesuai dengan sasaran pendidikan agama Islam.

a. Metode Pembelajaran dalam Kurikulum Ta'dib

Salah satu karakteristik pendidikan Islam yang dijelaskan dan dipraktikkan oleh al-Attas adalah keunikan metodologi yang disampaikannya, yaitu metode tauhid. Metode tauhid yang dimaksud disini adalah kepahaman keilmuan yang mesti selalu dikaitkan dengan ketauhidan seseorang kepada Penciptanya. Al-Attas merasa sedih dan kesal pada para sarjana dan cendikiawan yang merasa telah sempurna dan paham dalam memahami agama Islam. Kata al-Attas, semakin tinggi ilmu pengetahuan seseorang maka semakin tinggi pula ketauhidan dalam dirinya kepada Allah SWT (Wan Daud 1998).

Dalam hemat penulis, al-Attas ingin menyampaikan sikap kerendahan dan ketawadu'an dalam keilmuan. Bagi al-Attas, manusia yang sempurna adalah manusia yang senantiasa mengkoreksi kekurangan atau kesalahan dirinya sehingga tidak ada kata berhenti dalam belajar dan memahami luasnya ilmu pengetahuan. Semakin tinggi ilmu seseorang hamba maka semakin tinggi sikap ketawadu'an dalam dirinya.

Selain metode tauhid, al-Attas juga mengunakan metode metefora. Kata al-Attas metode tersebut juga banyak diterapkan dalam al-Qur'an dan Hadits. Metode metefora adalah menyampaikan pesan lewat perumpamaan-perumpamaan. Kata al-Attas, bagi orang beriman perumpamaan tersebut menambahkan keimanannya kepada
Allah SWT. Sedangkan bagi orang kafir perumpamaan tersebut menambahkan kefasikan dalam dirinya. Hal ini sebagaimana digambarkan dalam al-Qur'an surah Al-Baqoroh ayat 26, yang berbunyi:Artinya: "Sesungguhnya Allah tiada segan membuat perumpamaan berupa nyamuk atau yang lebih rendah dari itu. Adapun orang-orang yang beriman, Maka mereka yakin bahwa perumpamaan itu benar dari Tuhan mereka, tetapi mereka yang kafir mengatakan: "Apakah maksud Allah menjadikan ini untuk perumpamaan?." dengan perumpamaan itu banyak orang yang dibiarkanNya sesat, dan dengan perumpamaan itu (pula) banyak orang yang diberi-Nya petunjuk. dan tidak ada yang disesatkan Allah kecuali orang-orang yang fasik".

Kata al-Attas metode ini sangat penting dan baik bagi proses pengajaran, karena motede ini sebagaimana digunakan juga dalam al-Qur'an. Hal ini sebagaimana digambarkan dalam al-Qur'an surah Ibrahim ayat 24-26, yang berbunyiArtinya: “(24). Tidakkah kamu perhatikan bagaimana Allah telah membuat perumpamaan? Kalimat yang baik seperti pohon yang baik, yang akarnya teguh dan cabangnya menjulang ke langit; (25). Pohon itu memberikan buahnya pada Setiap musim dengan seizin Tuhannya. Allah membuat perumpamaan-perumpamaan itu untuk manusia supaya mereka selalu ingat; (26). Dan perumpamaan kalimat yang buruk seperti pohon yang buruk, yang telah dicabut dengan akar-akarnya dari permukaan bumi; tidak dapat tetap tegak" (Departemen Agama RI, 2005). 
Menurut pandangan penulis, pandangan al-Attas tentang metode tersebut di atas adalah suatu interpretasi atau gambaran metode yang disampaikan dalam al-Qur'an dan Hadis Rasulullah saw adalah sesuai dengan kondisi pendidikan umat Islam hari ini. Alasannya, segala sesuatu aktivitas umat Islam hari ini mesti kembali dikembalikan kepada sumber yang benar sehingga umat Islam dapat mengenal dan mengerti bahwa pendidikan Islam adalah sebuah wadah dalam mengembalikan pengenalan dan pemahaman yang benar dalam memahami hakikat dari ia mencari dan belajar serta menanamkan pendidikan dalam dirinya. Sehingga metode tauhid dapat dikatakan sebuah solusi dan jalan dalam membimbing arah yang benar bagi setiap penuntut ilmu dan pendidiknya. Sedangkan metode perumpaan yang disampaikan alAttas, menurut penulis, sangat penting untuk juga dikenal dan difahami, alasannya, tidak ada sesuatu yang terjadi dalam hidup ini secara kebetulan, karena sebagai orang yang beriman kita diperintahkan oleh Sang Maha Pencipta Allah SWT.untuk senantiasa berpikir dan memahami tentang segala yang diciptakan dan ditata oleh Allah SWT. sehingga tampak keMahabesaran dan Kerahmatan Allah SWT.sebagai seluruh makhluk-Nya. Hal ini jika dipahami akan menciptakan dan menambahkan iman yang benar dalam diri, selanjutnya menjadikan kita umat yang senantiasa sadar dan insaf akan tangungjawabnya kepada Allah SWT. dan senantiasa berusaha memperbaik setiap aspek dirinya ke tahap yang lebih sempurna. b. Materi-Materi Pembelajaran dalam Kurikulum Ta'dib

Menurut al-Attas, untuk menciptakan manusia sempurna atau universal (al-Insanul kamil) (AlAttas 1990). Maka setiap lembaga pendidikan mesti mengenal dan mengajarakan materi-materi kurikulum yang mencerminkan kesempurnaan manusia itu sendiri. Menurut al-Attas, materi kurikulum harus:Mencakupi aspek al-dunya dan al-akhirah, di mana aspek aldunya harus terkait secara harmonis dan mendalam dengan aspek alakhirah, sedangkan aspek al-akhirah harus diletakkan sebagai aspek terakhir lagi diutamakan" (Al-Attas 1990).

Al-Attas mengklasifikasikannya menjadi dua, yaitu ilmu-ilmu agama (fardu 'ain) dan Ilmu-ilmu rasional, intelektual dan filosofis (fardhu kifayah). Diantara dua pembagian ini ilmu-ilmu agama (fardu 'ain) adalah ilmu yang wajib dikuasai dan selalu dibenahi serta dipertahankan sesuai dengan tingkat ilmu-ilmu rasional, intelektual dan filosofis (fardhu kifayah) seseorang (Al-Attas 1990), Pembagian tersebut, yaitu:

1. Ilmu-ilmu agama (fardu 'ain), yaitu:

a) Al-Qur'an: pembacaan dan penafsirannya (tafsir dan ta'wil)

b) As-Sunnah: kehidupan Nabi, sejarah dan pesan-pesan para rasul sebelumnya, hadits dan riwayat-riwayat otoritatifnya.

c) Asy-Syari'ah: undang-undang dan hukum, prinsip-prinsip dan praktek-praktek Islam (Islam, Iman dan Ihsan)

d) Teologi: Tuhan, Esensi-Nya, Sifat-sifat dan Nama-nama- 
Nya serta Tindakan-tindakanNya.

e) Metafisika Islam:Psikologi, Kosmologi, dan Ontologi

f) Ilmu-ilmu Linguistik: Bahasa Arab, tata bahasa, leksikografi dan kesusasteraannya.

2. IImu-ilmu rasional, intelektual dan filosofis (fardhu kifayah), yaitu (Al-Attas 1990):

a) IImu-ilmu alam

b) IImu-ilmu terapan

c) Ilmu-ilmu teknologi.

d) IImu-ilmu kemanusiaan

Menururt penulis, pandangan al-Attas tentang materi-materi di atas sejalan dengan ajaran Islam dan pandangan pemikir ulung muslim di masa lalu, Imam al-Ghazali. Dapat dikatakan pandangan ini harus dikenal dan difahami kembali oleh umat Islam. Alasannya, melihat kondisi pendidikan Islam hari ini, di mana materi-materi pendidikan Islam sudah kurang memperhatikan urgensi dari ilmu fardu 'ain sebagaimana dijelaskan al-Attas di atas. Umat Islam telah meninggalkan pentingnya pengenalan dan pemahaman ilmu fardu 'ain secara kontinu (terusmenerus), akibatnya dunia Islam, khususnya pendidikan muslim hari ini mengalami kemunduran bila dibandingkan dengan dunia Barat. Jadi, solusi yang jujur yang mesti dilakukan sebagai langkah pertama bagi umat Islam adalah kembali mengenal dan memahami ilmu fardu 'ain sebagai yang utama dan terusmenerus sesuai dengan tingkat dan derajah masing-masing. Selanjutnya, barulah mengenal dan memahami ilmu fardu kifayah (ilmu pengkhususan). Semua pengenalan dan pemahaman tentang fardu 'ain dan fardu Kifayah mesti berada pada sumber, contoh dan amal yang benar, sehingga dapat menghantarkan dirinya kepada pengenalan dan pemahaman yang benar tentang Yang Maha Pencipta, Maha Pengasih, Maha Penyayang dan Maha Pemberi Rahmat Bagi seluruh alam, terkhusus bagi dirinya, sebagai makhluk yang terbaik yang diciptakan oleh Allah SWT.

\section{KESIMPULAN}

Kurikulum ta'dib dapat meningkatkan pembelajaran siswa dengan dua faktor utama yaitu Metode pembelajaran (yakni menggunakan Metode Tauhid dan Materi pembelajaran yang sesuai dengan sasaran pendidikan agama Islam, Yaitu:Ilmu-ilmu agama (fardu 'ain) dan Ilmu-ilmu rasional, intelektual dan filosofis (fardhu kifayah).

Faktor-faktor pendukung dan penghambat kurikulum berbasis ta'dib ini ialah: Kalangan orang tua yang melihat jauh kedepan, akan pentingnya karakter dan penanaman ilmu agama sejak dini.Sebagaian kalangan pendidik yang menginginkan generasi penerus bangsa mempunyai akhlak mulia dan selalu menjujung norma-norma menurut syariat agama.Sebagian kalangan pemerintah yang setuju akan kurikulum berbasis ta'dib dapat diterapkan di setiap lembaga pendidikan.

Faktor Penghambat Kebijakan kurikulum PAI Berbasis Ta'dib, ialah: a. Masalah konsep atau pemikiran pemerintah yang lebih mementingkan aspek kognitif dibandingkan dengan proses ta'dibnya peserta didik. b. Tujuan orang tua yang lebih mengedepankan ranah kognitif, sehingga melupakan akan 
karekteristik dan tingkah laku anak. b. Zaman yang terus menerus mengalami perubahan dan era globalisasi yang tinggi, sehingga mementingkan kognitif anak dari pada karakter anak. c. Kurangnya kesadaran pemerintah dalam kebijakan kurikulum yang berbasis agama, dalam peningkatan mutu pendidikan. d. Kurangnya kesadaran orang tua, dalam mengahdapai era globalisasi sekarang ini.

\section{DAFTAR PUSTAKA}

Abuddin Nata, 2003. KapitaSelektaPendidikanlslam, Bandung: Percetakan Angkasa.

Ahmad D. Marimba. 1981. PengantarFilsafatPendidikan/s/ am, Bandung: Al-Ma'rifat.

Dakir. 2004. Perencanaan dan Pengembangan Kurikulum, Jakarta: Rineka Cipta.

Departemen Agama RI. 2005. AlQuran dan Terjemahnya, Jakarta: Al-Huda.

Hasan Langgulung. 2000. AsasAsas Pendidikan Islam, Jakarta: PT. Al-Husna Zikra.

Husain Mazhahiri. 1999. Pintar Mendidik Anak, Jakarta: Lentera.

Moh. Yamin. 2009. Manajemen Mutu Kurikulum Pendidikan (Panduan Menciptakan Manajemen Mutu Pendidikan Berbasis Kurikulum yang Progresif dan Inspiratif, Yogyakarta: Diva Press.

Muhaimin. 2014. Pengembangan Kuurikulum Pendidikan Agama Islam di Sekolah, Madrasah dan Perguruan Tinggi, Jakarta: PT Raja Grafindo Persada.
Muhammad Ali 2005.

Pengembangan Kurikulum di Sekolah, Bandung: Sinar Baru.

Mushtafa. 2012. SejarahPendidikan Islam di Indonesia, Jakarta: Pustaka Setia.

Nana Sudjana. 1991. Pembinaan dan Pengembangan Kurikulum di Sekolah, Bandung: Sinar Baru.

Naquib Al-Attas. 1992. Konsep Pendidikan dalam Islam: Suatu Rangka Pikir Pembinaan Filsafat Pendidikan Islam, Bandung: Mizan.

Oemar Hamalik. 2007. Dasar-dasar Pengembangan Kurikulum, Bandung : PT. Remaja Rosdakarya.

Redja Mudyahardjo. 2014. Pengantar Pendidikan, Jakarta: PT Raja Grafindo Persada.

S. Nasution. 2006. Asas-Asas Kurikulum, Jakarta: Bumi Aksara.

Sudarsono. 1993. Etika Islam tentang Kenakalan Remaja, Jakarta: Renika Cipta.

Undang-Undang Republik Indonesia No 20 Tahun 2003 Tentang Sisitem Pendidikan Nasional (SISDIKNAS). 2010. Bandung: Fokusmedia. 